\title{
Public Service and Micro-Small Enterprise Developments in Indonesia
}

\author{
Metasari Kartika \\ Universitas Tanjungpura, Pontianak \\ metasarikartika@gmail.com
}

\begin{abstract}
This study aims to analyze the influence of public service on the Micro-Small Enterprise (MSE) developments in Indonesia. The study method used was regression analysis panel data with fixed effect approach; because of the limited data availability, the data was only taken from 20132015. The study findings show that public service and education projected by gross participation data have a positive influence on the development of MSE, while the economic growth and minimum wage policy have a negative influence on the development of MSE in Indonesia. Based on those findings, this study concludes that the public service in the form of government spending allocation policy, especially on the service and economic functions, will stimulate the increase of MSE numbers.
\end{abstract}

\section{Article Info}

- Received : August 23, 2018

- Revised : November 23, 2018

- Published : January 5, 2019

- No. Pages : 108-115

- DOI : 10.33019/ijbe.v3i1.103

- JEL : F63, L32

- Keywords : public, education, growth, wage, enterprise, business

\section{Introduction}

Government's role in allocating the budget to provide the public service will affect the business activity development in that region. The quality of availability and the convenience in accessing public facilities, especially those supporting the business improvement in MSE, will improve a region as well as allow it to compete with other regions. Ession, M-epbari, Nwikiabeh, \& Piabari (2016) concluded that there is a two-way causality between public spending with output and productivity of small, medium enterprises. Furthermore, public spending is still one of the instruments to increase the growth and development of the economy in Nigeria.

Indonesia's spending structure is based on eleven functions, two of which are general service function and economic function that the trend in recent thirteen years has shown improvement, only in 2015 to 2016 the spending of general service function was decreasing, but, also followed by the increasing of other functions' spending, including increasing in economic function (Badan Pusat Statistik, 2018). The general service spending is allocated to provide a quality public service that supports public activity, while the economic spending is allocated to the development of cooperative and small micro-enterprises (Kementerian Keuangan RI, 2018). 
Small and Medium Enterprise (SME) is proven to be the main tool adopted by a developed country to developing social-economic growth, in fact, SME is the main source of modern economy (Edoko, Ngige, \& Okoli, 2017; Muhammad, Char, Yasoa, \& Hassan, 2010). The main concern in micro, small and medium enterprise (MSME) is needed because these enterprises have roles in Indonesia's economy, for there are 57.895.721 business units, 114.144.082 workforces that contribute to GDP (based on constant price of 2000) around 1,526,918.8 billion, a total of non-oil and gas export 174,866.1 billion and IDR 341,341.6 billion investment (Ministry of Cooperative and Small and Medium Enterprise of the Republic of Indonesia, n.d). These business developments are not only influenced by government spending, but also by other factors. Adaramola \& Olugbenga (2012) stated that technology and financial support give a positive effect on the development of small-medium enterprises in Nigeria.

MSE problems related to the entrepreneur may come both internally and externally. The internal factors are education, experience, skill, and funding while the external factors are public services (facility and institutional), local economic growth, banking or investor roles, as well as regional minimum wage policy. This research will review factors that affect the development of MSE among public services, education, economic growth, and minimum wage factors.

\section{Literature Reviews}

Adolph Wagner creates the 'Law of the Increasing Extension of State Activity,' that furthermore known as Wagner Law. It is one of the theories that emphasize the economic growth as a fundamental determinant of public sector growths which becomes a focus of many empirical studies (Yuk, 2005). Wagner in Alfirman \& Sutriono (2006) stated theory about the development of government spending percentage that highly increases in gross domestic product. Wagner explains that if per capita income is increasing in the economy, the government spending will relatively increase in consequence. In this case, Wagner explains why the government has bigger roles, especially because the government needs to manage the relations that arise in society.

The proponents of SME policies argue that SME will improve the competitiveness and entrepreneurship because economically, SME has various benefits such as efficiency, innovation, and aggregate productivity growth. Government's support for SME will help the country to explore the social benefit of the competitiveness and the entrepreneurship. This shows that government spending on construction has a positive impact on the SME growth, whose indirect effect is in the form of public service and infrastructure and direct effect is in the form of special credit scheme sponsored by government and workshop program for SME (Tambunan, 2008).

Tambunan (2008) also reviews the controversy about the SME in the less developed country about SME in economic growth and the importance of government role in SME growth. His study aimed to re-examine the problem empirically with Indonesia data. The study finding showed that gross domestic product per capita and government's construction spending, especially those that fund the promotion of SME development which positively affects the SME growth. This study also concluded that the SME in a less developed country could sustain and even grow in a long-term because of three main reasons: (a) SMEs may create their own market, (b) SMEs activity is the source of income most of Indonesian, and (c) SME will grow along with big corporate because they have business relations in any form. 
Vial (2011) reviews the effect of financial, human capital, social capital, institution and the quality of infrastructure on household participation in micro-enterprises. Using panel data obtained from 13 provinces of Indonesia taken by Indonesia Family Life Survey (IFLS) in 1993, 1997, 2000 and 2007. This study concluded that urban households that have financial and social capital are more likely to participate in developing micro-enterprises. Education level is limited to the basic level, which means microenterprise becomes an alternative for limited employment opportunity for less-skilled labor. Furthermore, this study concluded that corruption in parliament and local government would decrease the number of micro-entrepreneurs, while the improvement in formal institution quality and infrastructure will increase the number of microenterprises.

Nichter \& Goldmark (2009) further explained about internal and external factors that influence the growth of small enterprises in the developing country. Internal factor is mostly related to the entrepreneur; such as education level, work experience, gender and household characteristic of the entrepreneur. The company age, sector (formal or informal), and access to finance is the characteristic key to company success. External factors include social networking, the chain of value and cooperation between companies, for example, the availability of supporting the market as well as contextual factors such as economic quality, institutional and infrastructure, which are also important factors that affect the small enterprises' growth.

Essien et al., (2016) studied the impact of public spending on output and productivity of small and medium enterprises in Nigeria year 1970-2015. The study finding showed there is long-term unidirectional causality between output and productivity of SME with public spending, but in the short term, the relationship is two-way. The conclusion of this research is public spending remains the short-term instrument that can be utilized to improve SMEs that push the economic growth and development in Nigeria.

Agyapong (2010) reviewed the importance of MSMEs for economic growth and reducing poverty. There are two different perspectives about MSME, the pro-MSME and anti-MSME. The pro-MSME believes that small enterprise has a significant role in economic prosperity in a country, whereas the anti-MSME believes that small bigger enterprise has a relatively significant role compared to MSME. The statement of anti-MSME does not apply in Ghana because most of the urban and rural areas have MSMEs that contribute to providing job opportunity, increase people's income and reduce poverty. Government's income from MSMEs is obtained from tax payment. The more MSMEs in society, the more revenue they can get through taxes. More MSMEs can also help reducing government spending on human resources development. If many MSMEs are assisted, many human resources can be trained that will lead to the development of human resources of a country. The government and investors should support MSMEs in creating jobs and increase society's living standard. As and the impact, MSMEs significantly contribute to the economy and work employment because they may stimulate economic growth, build links, improve human capital asset, and develop the society's entrepreneurship and skills.

Yean et al. (2016) re-identified the impact of minimum wage policy on small and medium enterprises in Malaysia. His research used descriptive and literature study methods in exploring further on how the minimum wage policy affects the competitive predominance and financial performance of a business manufacturing sector. The conclusion of the study is only a few micro 
and small enterprise that can apply minimum wage policy compared to bigger enterprises. The entrepreneur should develop effective measures to reduce the negative impact of the minimum wage that affects productivity. Those measures include training for workers, improving education, and investing in automation and advanced technology. With government and institutional support, as well as supervision and enforcement, it is hoped that the purpose of wage minimum policy implementation can be achieved.

Although in some literature there is debate between pro-SMEs and anti-SMEs (Agyapong, 2010; Tambunan, 2008b) but it cannot be denied that MSMEs have a role in the economy of a country (Edoko et al., 2017; Muhammad et al., 2010 ) Several empirical studies examined several factors in the development of MSMEs including public services through government spending or quality of infrastructure (Adaramola \& Olugbenga, 2012; Essien et al., 2016; Nichter \& Goldmark, 2009; Tambunan, 2008a), educational factors (Adaramola \& Olugbenga, 2012; Nichter \& Goldmark, 2009; Vial, 2011), economic growth (Tambunan, 2008a, 2008b), and minimum wage policies (Yean et al., 2016). Based on the structure of the problem, the purpose of the research and the literature review, the research hypothesis can be stated as follows: there is a positive relationship between public services, finance, education and economic growth towards the development of MSE in Indonesia.

\section{Research Methods}

This is a quantitative study. The objects of this study are the provinces in Indonesia, but due to limited data, it only covered 22 provinces within the 2013-2015 year period. The data used are secondary data, obtained from Central Statistical Agency (Badan Pusat Statistik), Bank Indonesia, and Directorate General of Fiscal Balance, Ministry of Finance Republic of Indonesia.

The data analysis method used is a multiple regression analysis models with the data panel method. A classic assumption test and statistic test will be done on the result of the calculation. According to the theory, framework, and hypothesis, as well as previous research, a model of the development of total MSEs as was created as follows:

$M S E=f(P S, E D U, G R O, M W)$.

The equations above can be expressed in the econometric model to describe the development of MSEs in Indonesia using this following formula:

$M S E_{i t}=\beta_{0}+\beta_{1} P S_{i t}+\beta_{2} E D U_{i t}+\beta_{3} G R O_{i t}+\beta_{4} M W_{i t}+\varepsilon_{i t} \ldots \ldots \ldots \ldots$ (3.2)

Notes:

MSE $_{i t}=$ Number of the micro-small enterprise of region-i, in year- $t$

$\mathrm{PS}_{\mathrm{it}} \quad=$ Regional public service of region-i, in year $\mathrm{t}$

$\mathrm{EDU}_{\mathrm{it}} \quad=$ Gross participation number of region-i, in year $\mathrm{t}$

$\mathrm{GRO}_{\text {it }}=$ Economic growth of region-i, in year $\mathrm{t}$

$\mathrm{MW}_{\mathrm{it}} \quad=$ Minimum wage of region-i, in year $\mathrm{t}$

$\varepsilon_{\text {it }} \quad=$ error term

$\beta_{0} \quad=$ Constanta

$\beta_{1}, \beta_{2}, \beta_{3}, \beta_{4}=$ estimated regression parameter

$\mathrm{i}=$ observed regency/city

$\mathrm{t}=$ observation period 


\section{Results}

Regression model finding results in regression model equation based on equation 3.2 as follows:

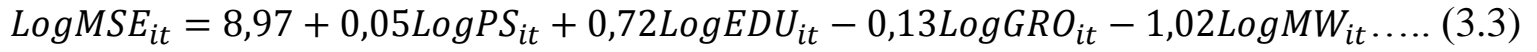

t-stat $(0,3027)(2.2275) * *(-2.3112) * *(-3.7952) * * *$

$\mathrm{R}^{2} \quad=0.997127$

$\operatorname{Prob}($ F-statistic $) \quad=0.000000$

Notes: ${ }^{* * *} \alpha=1 \% ; * * \alpha=5 \%$.

Data conversion into logarithms was done to reduce the variable value, in order to create value balance between one variable and another. Econometric experts often use this to solve data problems (Hujarati, 2004). Model equation 3.3 used fixed effect approach and pooled EGLS (cross-section weights) method. Fixed effect approach was chosen based on the result of the Chow test and the Hausman test (Table 1). The model has also passed the classic assumption test.

Table 1. Chow Test and Hausman Test Results

\begin{tabular}{|c|c|c|c|}
\hline Test & Probability & Significant level & Decision \\
\hline Chow & 0.0000 & 0.05 & Fixed Effect \\
\hline Hausman & 0.0080 & 0.05 & Fixed Effect \\
\hline
\end{tabular}

Source: Output Result

The findings of equation 3.3 are public services, and educations have a positive effect while economic growth and minimum wage policies have a negative effect on the number of MSEs in Indonesia. Public services, as a spending policy by the government, have a positive impact on the development of MSEs in Indonesia. Public services in this study are projected using government spending according to public service functions and economic functions.

The main target of the budget in the public service function is to improve the quality of bureaucracy; to be more professional, clean, and to serve as well as to increase public trust toward government through becoming more transparent, efficient, and effective in its bureaucratic governance (Ministry of Finance, 2018). Government spending according to the public service functions will aid several sub-functions, namely: (1) executive and legislative institutions, financial and fiscal issues, and foreign affairs, (2) public services, (3) basic research and development of science and technology, (4) regional development, (5) regional loans, (6) other public services.

Economic function spending supports the acceleration of an upgrade of economic growth and quality by strengthening economic driving force that is supported by the development of transportation, infrastructure, energy, food, as well as MSMEs and cooperatives growth (Ministry of Finance Republic of Indonesia, 2018). Government spending according to economic functions has these following subfunctions: (1) trade, business development, cooperative and SMEs, (2) labor, (3) agriculture, forestry, fisheries and marine, (4) irrigation, (5) fuel and energy, (6) mining, (7) industry and construction, (8) transportation, (9) telecommunication, and (10) other economies. 
Regression findings are in line with Wagner's theory and "Pro-SME Policy," which is the government role, in this case, through its spending that impacts the socio-economic life of the community. The Indonesian government has allocated its average spending around $49.5 \%$ for public service and $15.3 \%$ for the economy from total spending during 2010-2015. Both functions are mainly used to support the increase of MSE numbers in Indonesia. If those both functions are totalled, more than $50 \%$ of total government spending is meant to improve the service quality, which will eventually affect the number of MSEs in Indonesia. It was only in 2012 that there was a decline in MSEs growth, but it was increasing quantitatively. In the following years, both variables have the same pattern, that if the public service increases, the MSEs will also increase and vice versa (Figure 1).

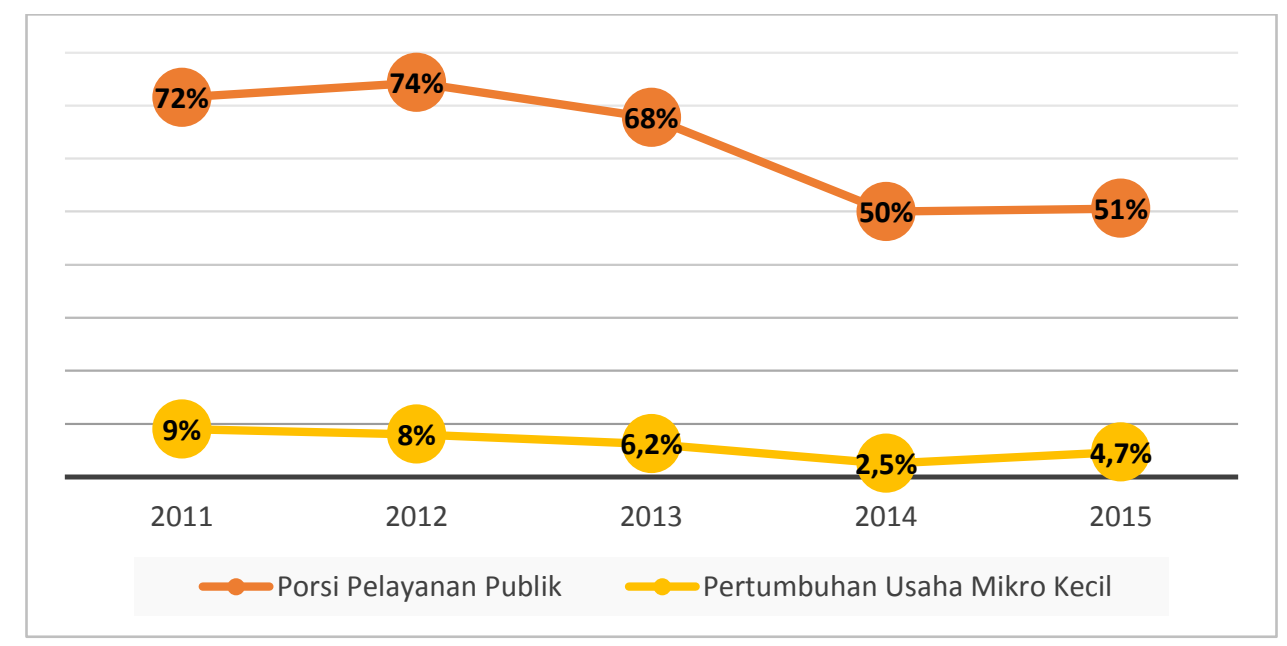

Source: Indonesian Central Statistical Agency

Figure 1. Public Service Portions and the Growth of MSE in Indonesia

A study by Ntiamoah, Li, \& Kwamega (2016) in Ghana also revealed that the government's support reflected by government's capacity in making policies, service, and investment in infrastructure and other supports would give a positive impact on MSE. Public services used by MSE will encourage them to be more innovative, create job vacancies, and develop locally and regionally, this will benefit the whole society (Nicholas \& Fruhmann, 2014).

MSEs are characterized by its labor-intensive dominance and free entry-free exit business structure, making it possible for the business to provide job vacancies. Employment is so competitive right now that the unemployed people are not only come from non-diploma people, but also those who have a diploma education background. MSE may become one of the solutions for this problem, by allowing them to create a free entry-free exit business as well as giving them a chance to become an entrepreneur in developing MSE.

The next variable that affects the number of MSEs in Indonesia is economic growth. Economic growth is one of the macroeconomic indicators that need to be maintained to keep the positive trend of people's purchasing power, business, and production. A stable or has an increasing tendency economic growth will provide opportunities for small micro entrepreneurs to grow their business to medium or big enterprises. If economic growth decreases, production costs will 
increase, making economic crisis unavoidable that may lead to unemployment, this will also increase the number of unemployed. These unemployed need to survive that they will eventually create an MSE. This situation had happened in Indonesia during the monetary crisis in 1997, 2008 and 2013 as well as 2015 when the economic growth dropped to 4.9\% from 5\% in 2014, resulting in some micro, small micro centre growth by $2.1 \%$ in 2015 from $2.5 \%$ in 2014 . The interesting fact is that during the crisis, MSEs were proven to survive because they had their market that did not link to the banks. According to Muhammad et al. (2010), furthermore, sustainable development and innovation are needed to encourage SMEs to become more competitive and able to compete in both domestic and global markets.

Other variables that have a negative influence on the MSEs in Indonesia is minimum wage. The minimum wage policy that is set turns out to have more impact on the development of MSE compared to big enterprises, due to the incompetence and the readiness of MSEs in financing their labors. In big enterprises, the minimum wage is effective in improving productivity, while according to The Stars (2012) in Yeam et al. (2016), if this policy is implemented, it may kill $80 \%$ SMEs. Another study in Thailand showed that SMEs are unable to comply with the minimum wage policy that they need government's compensations to overcome the impact of this policy (Sek-Choo, Tolos, \& Manab, 2016).

\section{Conclusion and Suggestion}

The study concluded that public service and education variables positively affect the MSEs development in Indonesia, while economic growth and minimum wage negatively affect the MSEs development in Indonesia. This result implies that public services provided by the government are necessary to improve the MSE's development both in its quantity and quality. Thus, it is hoped that both central government and local government could maintain or increase the budget that directly relates to people, especially the micro-small entrepreneurs. Public service provided will eventually encourage economic growth development, expectedly leads to the development of MSE to medium enterprises and big enterprises. Hence, a quality MSE is needed in order to make the more competitive, making it necessary to improve the entrepreneurs' capacities and skills. On the other hand, the minimum wage policy can be established, and the government may provide compensation for micro-small entrepreneurs.

\section{Acknowledgement}

I owe deep gratitude to the Faculty of Economics and Business of Tanjungpura University for funding this research. I also heartily thank Alsaufi, Tiwin, and Hartini for their help in completing this research.

\section{References}

1) Adaramola, \& Olugbenga, A. (2012). Policy Support and Performance of Small and Medium Scale Enterprises in South-West Nigeria. European Journal of Business and Management, 4(9), 10-19.

2) Agyapong, D. (2010). Micro, Small and Medium Enterprises ' Activities, Income Level and Poverty Reduction in Ghana - A Synthesis of Related Literature. International Journal of Business and Management, 5(12), 196-205.

3) Alfirman, L., \& Sutriono, E. (2006). Analisis Hubungan Pengeluaran Pemerintah dan Produk 
Domestik Bruto Dengan Menggunakan Pendekatan Granger Causality dan Vector Autoregression. Jurnal Keuangan Publik, 4(1), 25-66.

4) Badan Pusat Statistik. (2018). Belanja Pemerintah Pusat Berdasarkan Fungsi. Retrieved from https://www.bps.go.id/statictable/2014/01/13/1310/tabel-anggaran-belanja-pemerintah-pusatberdasarkan-fungsi-miliar-rupiah-2005-2017.html

5) Creswell, J. W. (2016). Research Design Pendekatan Metode Kualitatif, Kuantitatif, dan Campuran (Edisi Keem). Yogyakarta: Pustaka Pelajar.

6) Edoko, T. D., Ngige, C. D., \& Okoli, I. M. (2017). Government Antipoverty Programmes and Small and Medium Enterprises Performance in Nigeria. European Scientific Journal, 13(19), 371-394. https://doi.org/10.19044/esj.2017.v13n19p371

7) Essien, J. M., M-epbari, N., Nwikiabeh, L. B. M., \& Piabari, N. (2016). Impact of Government Spending on Small and Medium Scale Businesses in Nigeria. Equatorial Journal of Marketing and Insurance Policy, 1(2), 41-56.

8) Gujarati, D. N. (2004). Basic Econometrics Fourth Edition. Singapore: McGraw-Hill.

9) Kementerian Keuangan RI. (2018). Buku II Nota Keuangan Beserta Rancangan Anggaran Pendapatan dan Belanja Negara. Jakarta: Kementerian Keuangan RI. Retrieved from https://www.kemenkeu.go.id/media/10377/nota-keuangan-dan-rapbn-2019.pdf

10) Kementerian Koperasi dan Usaha Kecil dan Menengah RI. Data UMKM. Retrieved from http://www.depkop.go.id/berita-informasi/data-informasi/data-umkm/

11) Muhammad, M. Z., Char, A. K., Yasoa, M. R. bin, \& Hassan, Z. (2010). Small and Medium Enterprises ( SMEs ) Competing in the Global Business Environment: A Case of Malaysia. International Business Research, 3(1), 66-75.

12) Nicholas, C., \& Fruhmann, M. (2014). Small and Medium-sized Enterprises Policies in Public Procurement: Time for a rethink? Journal of Public Procurement, 14(3), 328-360. https://doi.org/http://dx.doi.org/10.1108/MRR-09-2015-0216

13) Nichter, S., \& Goldmark, L. (2009). Small Firm Growth in Developing Countries. World Development, 37(9), 1453-1464.

14) Ntiamoah, E. B., Li, D., \& Kwamega, M. (2016). Impact of Government and Other Institutions' Support on Performance of Small and Medium Enterprises in the Agribusiness Sector in Ghana. American Journal of Industrial and Business Management, 3(6), 558-567. https://doi.org/10.4236/ajibm.2016.65052

15) Sek-Choo, T., Tolos, H., \& Manab, N. A. (2016). Employee Benefits in Small Medium Enterprises (SMEs): Practice and Challenges. SSRN Electronic Journal, (August), 56-65.

16) Tambunan, T. (2008a). SME development, economic growth, and government intervention in a developing country: The Indonesian story. Journal of International Entrepreneurship, 6(4), 147-167. https://doi.org/10.1007/s10843-008-0025-7

17) Tambunan, T. (2008b). SMEs Development in Indonesia: Do Economic Growth and Government Support Matter. IJAPS, 4(2), 111-133.

18) Vial, V. (2011). Micro-Entrepreneurship In A Hostile Environment: Evidence From Indonesia. Bulletin of Indonesian Economic Studies, 47(2), 233-262. https://doi.org/10.1080/00074918.2011.585952

19) Wahyudi, S. T. (2016). Konsep dan Penerapan Ekonometrika Menggunakan E-views. Jakarta: PT RajaGrafindo Persada.

20) Yean, U. L., Ling, T. P., Yoke, C. C., Jayabalan, J., Fong, P. W., \& Kandasamy, S. (2016). The Impact of Minimum Wage Policy on Small Medium Enterprises' Productivity in the Manufacturing Sector. Journal of Business and Economics Review, 1(1), 78-83.

21) Yuk, W. (2005). Government Size And Economic Growth: Time-Series Evidence For The United Kingdom, 1830-1993. In Econometrics Working Paper. Department of the Economics University of Victoria. 